\title{
Do Labor Reforms in Spain Have an Effect on the Equilibrium Unemployment Rate?
}

\author{
Dionisio Ramirez ${ }^{1} \&$ Gabriel Rodríguez ${ }^{2}$ \\ ${ }^{1}$ Castilla-La Mancha University (UCLM), Derecho y Ciencias Sociales Faculty, Ciudad-Real, Spain \\ ${ }^{2}$ Department of Economics, Pontificia Universidad Católica del Perú (PUCP), Lima, Peru \\ Correspondence: Gabriel Rodríguez, Department of Economics, Pontificia Universidad Católica del Perú \\ (PUCP), Av. Universitaria 1801, Lima 32, Perú. E-mail: gabriel.rodriguez@edu.pucp.pe
}

Received: August 2, 2013 Accepted: August 24, 2013 Available online: November 11, 2013

doi:10.11114/ijsss.v2i1.194 URL: http://dx.doi.org/10.11114/ijsss.v2i1.194

\begin{abstract}
In this paper, we analyze the impact of several labor reforms in Spain on its equilibrium unemployment rate. To this end, we analyzed the behavior of the observed unemployment rate in Spain during the 1976-2012 period, thereby assessing whether that rate is better characterized as a hysteresis process or, on the contrary, as a stationary process with fluctuations around an equilibrium unemployment rate (NAIRU). In order to achieve this aim, we employed unit root contrasts with structural change. Similarly, in order to calculate the equilibrium unemployment rate, we applied the methodology of multiple structural changes proposed by Bai \& Perron (1998, 2003a). This method allows the estimation of breaking dates and the values of unemployment rates for each of the selected regimes. Lastly, we compare the direction in the changes of the equilibrium unemployment rate, as well as the dates of those breaking points, with the dates in which different labor reforms were enacted in Spain. This will allow us to determine whether those reforms had any effect on the Spanish labor market. The obtained results suggest that only the reforms of 1980, 1997 and 2006 had some influence on the equilibrium unemployment rate level in combination with changes in inflation and sectorial employment structure.
\end{abstract}

Keywords: unemployment rate, NAIRU, unit roots, structural change, labor reform

\section{Introduction}

Unemployment is one of Spain's main current macroeconomic disequilibria. The unemployment rate of the Spanish economy in 2013, at 27\%, is more than double the European Union's, a circumstance that is not new for our country. The high levels in the unemployment rate are one of the key features of the Spanish economy. Thus, in the 1980 's unemployment reached $20 \%$ and in the 90 's it surpassed $22 \%$. One additional feature is the high persistence of unemployment. When the economic recovery began in 1985, the unemployment rate did not retreat below the levels of before the onset of the recession. Similarly, although the recovery that started in 1995 reduced notably the unemployment rate in Spain, it still remained at levels double the European Union's mean for several years before reducing the gap and reaching $7.9 \%$, slightly above the European mean, in the second quarter of 2007.

According to a report on Spanish unemployment by the Centre for Economic Policy Research (CEPR, 1994), one possible explanation of this variable's performance would reside in the evolution of the equilibrium unemployment rate, which, for its part, might reflect structural problems in the labor market.

There are two possible theoretical frameworks for analyzing variations in the equilibrium rate. The first one, known as hysteresis (Blanchard \& Summers, 1986), hypothesizes that cyclical fluctuations have permanent effects on the unemployment rate. In this case the observed unemployment depends on its past values, and thus it will never reach its equilibrium level. That is, all shocks have a permanent impact on the equilibrium rate.

The second approach, called structural, posits that the path of the unemployment rate always approximates the equilibrium rate. However, as Phelps (1994) points out, that rate shifts in time, such that if most shocks cause temporal changes in the observed equilibrium rate and around the equilibrium level, it is highly probable that some shocks cause permanent changes in that equilibrium rate.

There is a large number of publications at an international level that have attempted to determine whether the path of a country's or region's unemployment rate can be explained through a hysteresis model or rather by the structural hypothesis by analyzing the stationarity or lack thereof in the unemployment rate. Studies such as 
Blanchard \& Summers (1986), Jaeger \& Parkinson (1994), Roed (1996) or Payne et al. (1999) established that the persistence in unemployment rates indicates that the most appropriate model to account for their behavior is the hysteresis hypothesis. Unfortunately, the statistical contrasts that were utilized are not robust against the presence of structural change of the type considered by Perron (1989), so that a lot of the persistence shown by these rates can be considered spurious as a consequence of not taking those breaks into account. Once this effect is detected and corrected, the persistence decreases significantly and, as several authors have consequently shown (Mitchell, 1993; Arestis \& Mariscal, 1999, 2000; Papell et al., 2000; Ewing \& Wunnava, 2001; Camarero et al., 2005; Clemente et al., 2005), the evidence in favor of the hysteresis models is greatly diminished.

In both cases (hysteresis and structural model), the rigidities in the labor market can affect the behavior in the unemployment rate. In order to eliminate those rigidities, from 1980 onwards several labor reforms have been enacted with the aim of increasing flexibility in the labor market and hence of achieving lower unemployment levels.

As shown by Saint-Paul (2002b) in the European context, a labor reform entails changing regulations that hinder the working of the job market and that, in his view, have led to abnormally high levels in terms of unemployment levels and their duration.

In the case of Spain, one finds multiple studies of varying technical complexity that seek to evaluate the effects of one or more labor market reforms on the job market. The results of those studies are ambiguous and depend on the analyzed period and the reforms in question. Thus, Escudero et al. (2004) conclude that the reforms of 1994, 1997 and 2001 might have played a significant role, but in any case a definitive one. For their part, Conde-Ruiz, Felgueroso and García (2010) estimate that the impact of the 2006 reform was very limited, whereas Estrada et al. (2011) assess positively the reform of 2010, specially regarding its long-run effects.

Although it is relatively easy to find studies that quantify the effects of a labor reform on the observed unemployment rate in Spain, it is somewhat more difficult to find others that gauge the effect of a labor reform on the equilibrium unemployment rate. This is due to two reasons: first, such equilibrium rate is not directly observable and must be inferred from the data. Second, the changes occurring to this variable must be estimated in a robust way, and relate them to the "structural" reforms.

One of the most commonly used approaches in analyzing the equilibrium unemployment rate is the concept of NAIRU (Non-Accelerating Inflation Rate of Unemployment). Such concept was introduced by Modigliani \& Papademos (1975) as an attempt to reconcile the theory of the Phillips Curve with the monetarist critiques. NAIRU is the rate of unemployment at which inflation remains stable. (Note 1)

The Spanish equilibrium unemployment rate based on NAIRU has been estimated in several studies (Dolado et al., 1986; Andrés et al., 1988; Andrés et al., 1996; Dirección General de Previsión y Coyuntura (DGPC), 1991; De Lamo \& Dolado, 1993; Jimeno \& Toharia, 1992; Rodríguez-Prado, 1995a, 1995b; Blanchard \& Jimeno, 1999; Bellod, 1999; Montero, 2000; Estrada et al., 2002; McMorrow \& Roeger, 2000; Durán \& Ramos, 2006) and, in general, its value depends on the techniques applied by different authors. Nevertheless, according to F. Gómez \& Usabiaga (2001b), the results of these papers point to a lack of robustness, as well as the existence of problems in specification and inconsistency. For this reason, the estimations vary considerably depending on the period under consideration or the methodology employed, and those papers that provide standard errors or confidence intervals show large amplitude in them. (Note 2)

In general, the conclusions arrived at in the papers — domestic and international- (Siebert, 1997; Blanchard \& Wolfers, 1999; OECD, 1999; Bentolila \& Jimeno, 2006; Escudero et al., 2004; Blanchard, 2006) that have studied the relation between labor reforms and their impact on the equilibrium unemployment rate, point all in the same direction: there is a close relation between the equilibrium unemployment rate and the elimination of rigidities in the job market.

In this study, we aim to determine whether, for the sample period between 1976 and 2012, any of the many labor reforms applied on the Spanish job market has had effects on the equilibrium unemployment rate. To this end, we analyze through a time series methodology, whether the unemployment rate in Spain follows a hysteresis pattern or a structural one. The first one would be associated to the phase of the business cycle, so that any kind of shock (temporal or structural) would have effects on the unemployment rate, whereas the second one would be linked to the existence of a constant equilibrium rate that, eventually, would be subject to changes in its level.

On the basis of our results, we reject the existence of a process of hysteresis in the unemployment rate; by the methodology of Bai \& Perron $(1998,2003 a, 2003 b)$ it is possible not only to estimate an adequate value of NAIRU, but also to detect the number and the moment at which changes in the magnitude of that variable take place, within very tight confidence intervals. Additionally, we compared the dates in which those changes took place with the dates at which the different labor reforms were enacted, hoping to find some kind of coincidence 
in time. According to that comparison, only three labor reforms appear to have affected the equilibrium unemployment rate with diverse results.

This paper is organized as follows: in section 2 we review the different labor reforms that have taken place in Spain and their effect on the observed unemployment rate. In section 3 we develop the theory that will allow us to find out the behavior of the unemployment rate and to estimate its equilibrium value. In section 4, we show the empirical results of the proposed methodology as applied to the unemployment rate in Spain. Section 5 presents our conclusions.

\section{Descriptive Analysis of the Impact of Labor Reforms in Spain}

This paper's sample period covers up to seven important labor reforms, starting from the first Workers' Statute of 1980 until the last reform of 2012. The Workers' Statute of 1980 can be considered the first big labor reform in Spain.

On the basis of several works (Malo \& Toharia, 1997; Segura, 2001; Palacio \& Álvarez, 2004; Ruiz, 2006; S. Gómez et al., 2008; Andrés et al., 2012), we establish the following timeline of regulatory changes in the Spanish job market, and we present a brief summary of the most distinguished aspects of each of those reforms (Note 3):

First Reform: March 1980

The first Workers' Statute brought the definitive "normalization" of labor relations in Spain, by defining the regulatory framework in which the three pillars of the job market were established in the country (Note 4):

- The different types of contract and their termination

- Direct workers' representation

- Collective bargaining and agreements

Second Reform: October 1984

It was the first amendment to the Workers' Statute of 1980. Developed different aspects of collective bargaining and included novel changes although, without a doubt, the most important one was the introduction of new modes of temporary hiring.

Third Reform: June 1994

It was a reform of wide range, brought about by the necessities of both the delicate economic situation in Spain, as well as the need to compete within the framework of the European Union. The aims of this reform were focused on the reduction of the high prevalence of temporary jobs, the reduction of youth unemployment, the increasing of flexibility of the job market by increasing the motives for objective layoffs, and the legalization of temporary work companies and the popularization of internship contracts.

Fourth Reform: May 1997

Although the economic recovery period was underway, the high level of unemployment and the excessive percentage of temporary contracts in the job market led the reform to focus on three aspects: to increase indefinite hiring (introducing a new permanent contract with compensation for inappropriate layoffs aimed at young workers, women and workers aged 45 or more), to limit and control temporary contracts, and to modify the conditions of initial work contracts.

Fifth Reform: March 2001.

In a much better job context than in previous years, the path taken in 1997 is continued, in such a way that the previously adopted measures are amplified. Besides, part-time hiring is encouraged and the conversion of temporary into permanent contracts is incentivized.

Sixth Reform: May 2006

During the boom years that were fueled by the real estate sector, the main problem in the job market was the fragility of labor contracts, and an effort was made to curb the proliferation of temporary jobs. Additionally, one should not forget that, despite the good performance of the Spanish economic, its job market had low rates of women's participation and the unemployment rate was double the European mean. This disparity was especially acute in the case of young workers, women and persons with disabilities. Thus, the reform was focused on boosting permanent hiring, improving the utilization of temporary hiring, and increasing unemployment protection of specific demographics.

Seventh Reform: June 2010

In the midst of one of the worst economic downturns known to date, the current government approves its second 
labor reform. This reform attempts to correct some of the inefficiencies that characterize the Spanish job market, such as the excessive segmentation between workers with permanent contracts and those under temporary status; the absence of flexibility to adapt companies' labor situations to their particular circumstances or those of their sector; the lack of efficiency in job market intermediation; and the need to improve the qualification of the less-educated workforce. In order to achieve this, the regulations enable companies under certain circumstances to compensate redundant workers with 20 days per year instead of the usual 45 . One additional element of reform is the expansion of the permanent contract with 33 days of compensation, and the possibility of companies under economic duress to modify the working conditions of their staff. In exchange, limits are finally put in place to temporary contracts for work or service.

Eighth Reform: February 2012

Deep in what is already known as the "Great Recession" and with Spain at the center of the sovereign debt market crisis, the latest job market reform introduces important changes into the system of labor relations regarding collective bargaining, internal flexibility and layoff regulations. On the one hand, company agreements are given priority, the economic cause of layoffs is determined, and a limit is set on the automatic extension of lapsed agreements. Similarly, the possibility of unilateral changes in agreed salaries is explicitly allowed for the first time, when these are higher than those negotiated upon by agreement. On the other hand, many aspects of employment protection are modified, although the most relevant measures have only one aim: to reduce layoff compensations in order to bring them closer to the average levels of the rest of European countries.

Modern economic theory (Bentolila \& Bertola, 1990; Hopenhayn \& Rogerson, 1993; Saint-Paul, 1995, 1997, 2002a, 2002b) predicts a triple impact of the reduction of rigidities in employment protection legislation. In the first place, a job-destruction process takes place in low-productivity jobs that previously only existed because it was less costly for companies to keep losing money by keeping workers at the company than by terminating their contracts and paying layoff compensation. The workers affected by such perspectives are prone to oppose reform, unless they are compensated. Secondly, there is a reduction in employment protection that translates into an increase in the creation of jobs due to the reduction in total labor costs. However, it bears highlighting that the net effect on the reduction of the unemployment level is not clear in net terms: there are both job-creation and job-destruction processes at work. Thirdly, an increase in salaries ensues, at least after some time has passed, which reflects a pressure on the job market due to the creation of new jobs. However, this increase in salaries is also another side of the fact that workers are more productive, since the low-productivity jobs have been eliminated.

On the basis of the present review of labor reforms enacted in the country, we can state that the regulatory changes in the Spanish labor market tend to combine measures with conflicting effects on jobs and unemployment. Thus, for example, when the costs of layoffs are reduced at the same time that the quantity and duration of unemployment benefits are reduced, it is difficult to assess the impact of these measures on the job market.

A first approach, in this sense, would consist in carrying out a simple descriptive analysis that establishes a "timeline" with the mean yearly unemployment rates, distinguishing the different periods that intervene between reforms. In Table 1, we can find periods in which, after a labor reform, the rate of unemployment increases on some occasions and diminishes in others. Although one has to take into account that sometimes the objective of these reforms has not been to "make the job market more flexible" as much as to end its precariousness, in all of them one finds elements that seek to eliminate the rigidities in the labor market in order to encourage job-creation. As such, there is contradictory evidence with respect to the fact that, in the period following a labor reform, the unemployment rate increases.

Table 1. Unemployment Rate, Labor Reforms and GDP

\begin{tabular}{llcc}
\hline Labor Reforms & Period & Average change of unemployment rate & Average change of GDP* \\
\hline March 1980 & $1977-1980$ & $25.3 \%$ & $1.4 \%$ \\
October 1984 & $1981-1984$ & $14.6 \%$ & $1.1 \%$ \\
June 1994 & $1985-1994$ & $1.5 \%$ & $2.9 \%$ \\
May 1997 & $1995-1997$ & $-5.9 \%$ & $3.0 \%$ \\
March 2001 & $1998-2001$ & $-12.3 \%$ & $4.4 \%$ \\
May 2006 & $2002-2006$ & $-3.8 \%$ & $3.3 \%$ \\
June 2010 & $2007-2010$ & $26.1 \%$ & $0.1 \%$ \\
February 2012 & $2011-2012$ & $11.7 \%$ & \\
\hline
\end{tabular}

Source: Compiled from Labor Force Survey (LFS) of the National Institute of Statistics (INE) and Annual Database of Spanish Economy BDMacro of the Ministry for Finance and Public Administrations (MINHAP).

Notes: * Data available until 2010. 
One possible explanation to this phenomenon is that the effects on the job market will depend on the interaction with the shocks that affect the economy at a particular moment, that is, at the stage of the business cycle at which the reform is started (Escudero et al., 2004; Saint-Paul, 2002b; Bentolila, 2013). In this way, if the "impact" effect of the reduction in employment protection is the massive destruction of jobs, its social cost is probably lower at expansionary stages, since companies are more inclined to hire workers in such circumstances. (Note 5)

Thus, if we establish a comparison between the mean variation of the observed unemployment rate and GDP, taking into account the previously established periods in relation to the years in which the labor reforms took place, we can appreciate (see Table 1) that in the periods of lower growth in the Spanish economy - especially, below 3\%-, the unemployment rate increases. The opposite occurs when growth is above $3 \%$.

In consequence, we could conclude that, in the short term, the effect of a labor reform will depend on the business cycle. The increase in flexibility in the job market leads to a higher unemployment rate during contraction or low-growth periods, and encourages job-creation during expansion periods, thus reducing the unemployment rate.

Nevertheless, the existence of high unemployment rates in the country for long periods of time, beyond short-term effects, can be attributed to either the existence of a hysteresis process or to the existence of a high equilibrium unemployment rate. In both cases, in consequence, the attainment of low levels in the observed unemployment rate will depend on the capacity of the Spanish economy to reach, in the long term, a lower structural unemployment level. In this sense, the labor reforms must contribute to achieve that objective depending on whether their effects are permanent or transitory. In consequence, the question to be asked is whether those reforms have had any structural effect. In order to shed light on that question, we proceed in the following section with a unit root analysis.

\section{Methods}

\subsection{Unit Root Test and Structural Changes}

In line with the strategy proposed by Papell et al. (2000), the key to determine whether a job market works according to a hysteresis or structural model is to determine whether a unit root in the unemployment rate exists, by using unit root tests. However, DeJong et al. (1992) show that this type of test have problems of power, so that they are not able to distinguish series with unit root from others that follow an autoregressive process of order one - $\mathrm{AR}(1)$ - with a coefficient that is close, but below unity.

In consequence, in this paper we will use the more powerful statistics proposed by Elliott et al. (1996), which will be denoted $A D F^{G L S}$ and $P T^{G L S}$. Similarly, we will use the M statistics, initially proposed by Stock (1999) and analyzed by $\mathrm{Ng} \&$ Perron (1996). Those tests will be also used in their GLS version and the lag will be chosen using the modified AIC criterion (MAIC), as proposed by Ng \& Perron (2001).

The series under analysis will be denoted by $\tilde{y}_{t}=y_{t}-\hat{\psi}^{\prime} z_{t}$, where $\hat{\psi}^{\prime}$ are the GLS coefficients obtained from a OLS regression of $y_{t}^{\widehat{\alpha}}$ versus $x_{t}^{\widehat{\alpha}}$ where $y_{t}^{\widehat{\alpha}}=(1-\hat{\alpha} L) y_{t}$ and $z_{t}^{\widehat{\alpha}}=(1-\hat{\alpha} L) z_{t}$ for $t=2, \ldots, T$, $y_{1}^{\widehat{\alpha}}=y_{1}$ and $z_{1}^{\widehat{\alpha}}=z_{1}$, and where $z_{t}$ is a set of deterministic components. In general, $z_{t}=\{1\}$ or $z_{t}=\{1, t\}$ when regressions include an intercept or an intercept and a linear trend, respectively. The series $\tilde{y}_{t} t$ thus obtained is denominated "GLS demeaned" or "GLS detrended series", as recommended by Elliott et al. (1996).

The first statistic is the so-called Augmented Dickey-Fuller (ADF ${ }^{\mathrm{GLS}}$ ):

$$
\Delta \tilde{y}_{t}=\rho_{0} \tilde{y}_{t-1}+\sum_{j=1}^{k} b_{j} \Delta \tilde{y}_{t-j}+e_{t k},
$$

where the $\mathrm{k}$ lags of variable $\Delta \tilde{y}_{t-j}$ are added in order to eliminate the possible autocorrelation pattern. Through the estimation of equation (1) we prove whether the autoregressive parameter $\rho_{0}$ equals 0 . If the null hypothesis $\mathrm{H}_{\mathrm{o}}$ : I(1) is not rejected, this implies that the value of the unemployment rate at time $t$ depends on its past value in $t-1$, so that the shocks have permanent effects and the hysteresis theory will be supported. On the opposite, if that hypothesis is rejected one can state that the shocks affecting the unemployment rate have a transitory effect and, thus, that these rates will fluctuate around a medium value, which can be interpreted as evidence in favor of the existence of an equilibrium unemployment rate. The so-called $\mathrm{M}$ tests are defined by:

$$
\begin{gathered}
M Z_{\alpha}^{G L S}=\left(T^{-1} \tilde{y}_{T}^{2}-s^{2}\right)\left(2 T^{-2} \sum_{t=1}^{T} \tilde{y}_{t-1}^{2}\right)^{-1}, \\
M S B^{G L S}=\left(T^{-2} \sum_{t=1}^{T} \tilde{y}_{t-1}^{2} / s^{2}\right)^{1 / 2}, \\
M Z_{t}^{G L S}=\left(T^{-1} \tilde{y}_{T}^{2}-s^{2}\right)\left(4 s^{2} T^{-2} \sum_{t=1}^{T} \tilde{y}_{t-1}^{2}\right)^{-1 / 2},
\end{gathered}
$$

where $s^{2}$ is an estimator of the spectral density at zero frequency defined as $s^{2}=s_{e k}^{2} /(1-\hat{b}(1))^{2}$ with $s_{e k}^{2}=(T-k)^{-1} \sum_{t=k+1}^{T} \hat{e}_{t k}^{2}, \hat{b}(1)=\sum_{j=1}^{k} \hat{b}_{j}$, and $\hat{b}_{j},\left\{\hat{e}_{t k}\right\}$ are obtained from regression (1); see Perron $\& \mathrm{Ng}$ 
(1998). The first statistic is a modified version of the $Z_{\alpha}$ test by Phillips \& Perron (1988), originally developed by Phillips (1987). The second statistic is a modified versión of the statistic suggested by Bhargava (1986). The third statistic is a modification of the $Z_{t}$ statistic by Phillips \& Perron (1988).

Finally, the test denominated optimal in a point of the alternative is defined as follows:

$$
P_{T}^{G L S}=[S(\bar{\alpha})-\bar{\alpha} S(1)] / s^{2},
$$

where $S(\bar{\alpha})$ and $S(1)$ are the sums of squared residuals of a GLS regression under the alternative and null hypothesis, respectively.

However, the existence of structural changes in the evolution of the unemployment rate is an important source of distortions in the inference of unit root tests. Such changes can lead to erroneously accepting the hypothesis of unit root due to their low power under conditions of an incorrect specification of the alternative hypothesis (Perron, 1989, 1994; Montañés \& Reyes, 1998). For this reason, we apply the unit root statistics suggested in (1)-(5) with structural breaks as proposed by Perron \& Rodríguez (2003), using the GLS procedure as previously mentioned. The difference in this case is that $z_{t}=\left\{1, t, 1\left(t>T_{B}\right)\left(t-T_{B}\right)\right\}$ or $z_{t}=\left\{1,1\left(t>T_{B}\right), t, 1(t>\right.$ $\left.\left.T_{B}\right)\left(t-T_{B}\right)\right\}$. The break point is chosen by using the method suggested by Zivot \& Andrews (1992) that is, choosing such point which minimizes the value of each previously mentioned unit root statistics. (Note 6)

Once the series are stationary with structural breaks, the methodology of Bai \& Perron $(1998,2003 \mathrm{a}, 2003 \mathrm{~b})$ is applied. The Bai-Perron procedure is based on the principle of global minimizers of the squared sum of residuals, and is capable of determining the number of structural changes in a consistent fashion. Bai \& Perron (1998) consider the following general model with $m$ break points $(m+1$ regimes):

$$
y_{t}=x_{t}^{\prime} \beta+z_{t}^{\prime} \delta_{j}+\varepsilon_{t},
$$

where $y_{t}$ is the dependent variable, $x_{t}(p \times 1)$ and $z_{t}(q \times 1)$ are the vectors of independent variables (the first being a vector of exogenous variables and the second a vector of deterministic variables such as the intercept, the trend, or the lagged endogenous variable); $\beta$ and $\delta_{j}(j=1, \ldots, m+1)$ are the corresponding vectors of coefficients; $\varepsilon_{t}$ is a random disturbance that could behave according to a wide variety of stationary models, including the general ARMA model; and $T B_{i}, \ldots, T B_{m}$ are the break points treated as endogenous by the model. The model admits partial structural changes. However, in the present case we will estimate a model with pure structural change, in which all parameters change and the variables $x_{t}$ do not exist.

The linear model with $m$ break points represented in equation (6), according to Clemente et al. (2005), can be expressed as:

$$
y_{t}=\mu_{j}+v_{j}, \quad t=T B_{j-1}, \ldots, T B_{j}, \quad j=1,2, \ldots, m+1
$$

where $\mu_{j}$ groups all model parameters and $v_{t}$ is the random innovation. The procedure of Bai \& Perron considers that the structural change can appear in any period of the sample. The presence of multiple structural changes is analyzed by using different statistics. Two of them are the so-called $U D_{\max }$ and $W D_{\max }$ statistics, which test the null hypothesis of no break against the presence of an unknown number of breaks. Another statistic is the one called supF test, which verifies the null hypothesis of zero breaks agains an alternative number of $\mathrm{h}$ breaks. Another statistic is $\sup F_{T}(l \mid l)$, against $\sup F_{T}(l+1 \mid l)$, where the procedure is sequential. Additionally, the number of breaks can be obtained using information criteria such as BIC and LWZ (Liu et al., 1997). For further detail, see Bai \& Perron (1998, 2003a, 2003b).

The utilized strategy will consist initially in the use of unit root contrasts. Once the stationarity of the time series has been demonstrated, the Bai-Perron procedure will be applied in order to estimate the number of structural changes, the periods during which the breaks appear, and finally, the mean of the variable in each of the regimes.

In order to obtain the equilibrium unemployment rate we will follow the theoretical framework of Layard et al. (1991), which is based on the equations for price and wage setting instead of labor demand and supply functions. Thus, the prices will depend on a mark-up over expected salaries, whereas salaries will depend on a mark-up over expected prices. Two equations are thus obtained:

$$
\begin{aligned}
& p-w^{e}=\beta_{0}-\beta_{1} u \\
& w-p^{e}=\gamma_{0}-\gamma_{1} u
\end{aligned}
$$

where $p$ (prices) and $w$ (nominal wages) are expressed in neperian logarithms; $u$ is the unemployment rate; $\beta_{0}$ and $\gamma_{0}$ are the parameters representing the mark-up (or pulse parameters); and $\beta_{I}$ and $\gamma_{1}$ are the parameters that represent the model's flexibility. It is assumed that parameters $\beta_{0}, \beta_{1}, \gamma_{0}$ and $\gamma_{1}>0$ and that, besides, they are determined by different factors. 
Additionally, it is assumed that both prices and nominal wages follow a random walk, so that in the long term $w^{e}$ $=w$ and $p^{e}=p$. From equations (8) and (9), we obtain that the equilibrium unemployment rate is:

$$
u^{*}=\frac{\beta_{0}+\gamma_{0}}{\beta_{1}+\gamma_{1}}
$$

However, this unemployment rate can be modified due to changes in the structural parameters associated to institutional factors such as changes in the minimum wage, in unemployment benefits, etc. These "nominal surprises" give place to errors in the setting of expectations of economic agents, so that $w^{e}=w=p^{e}=p \neq 0$. In consequence, the shifts in the observed unemployment rate will depend on the existence of a process of acceleration or deceleration in prices or, equivalently, in nominal wages:

$$
u=u^{*}-\frac{p-p^{e}}{\theta_{1}}
$$

where $\theta_{1}=\frac{\left(\beta_{1}+\gamma_{1}\right)}{2}$. If we assume that inflation follows a random walk and, in consequence, the variations in inflation are stationary, we will obtain:

$$
\Delta p=\Delta p_{-1}+\varepsilon
$$

where $\varepsilon$ is a random stationary disturbance, which implies that (Note 7):

$$
p^{e}=E(p)=p_{-1}-\Delta p_{-1}
$$

and where the classic Phillips curve can be obtained:

$$
u=u^{*}-\frac{\Delta p-\Delta p_{-1}}{\theta_{1}}
$$

As a result, one can state that shifts in the unemployment rate round its natural rate depend on the evolution of prices or, lacking these, of nominal wages. Equation (14) can be formulated as follows:

$$
u=u^{*}-\frac{1}{\theta_{1}}\left(\Delta p-\Delta p_{-1}\right)=u^{*}+v
$$

Starting from equation (15), one can appreciate that the value of the observed unemployment rate depends on the equilibrium or NAIRU plus a $(v)$ component that determines the cyclical movement. In the case of the existence of $m$ break points, the unemployment rate is best defined as:

$$
u^{*}=u_{j}^{*}+v, \quad j=1,2, \ldots, m+1
$$

Once the periods in which the structural change takes place are defined, one can estimate the values of NAIRU. If we compare equation (16) with (7), we can conclude that:

$$
\hat{\mathrm{u}}_{t}^{*}=\hat{\mu}_{j}, \quad t=T B_{j-1}, \ldots, T B_{j}, \quad j=1,2, \ldots, m+1
$$

The approach by Clemente et al. (2005) allows us to obtain a simple estimation of the equilibrium unemployment rate or long-run NAIRU through the estimation of the $\hat{\mu}_{j}$, parameter of model (7), using the Bai-Perron (1998) procedure. However, one must not forget the fact that, as the authors have pointed out, this estimation is based on a time series approach where NAIRU is calculated as the "local" mean of the observed

\begin{tabular}{|c|c|c|c|c|c|c|}
\hline Model* & $A D F^{G L S}$ & $M Z_{\alpha}$ & $M Z_{t}$ & $M S B$ & $M P_{T}$ & $k^{* * *}$ \\
\hline Constant & -0.293 & -2.550 & -0.845 & 0.331 & 8.440 & 9 \\
\hline Constant \& Trend & -1.655 & -8.944 & -2.085 & 0.233 & 10.304 & 5 \\
\hline
\end{tabular}
unemployment rate, so that this method does not allow to analyze the structural determinants of the equilibrium rate. However, instead, the Bai-Perron method allows us to obtain the number of structural changes, the moment at which they take place, and their respective confidence intervals.

\section{Results}

We analyzed the time series properties of the unemployment rate in Spain by using unit root contrasts for the sample period between $1976 Q 3$ and 2012Q2. (Note 8)

Table 2. Unit Root Tests without a Structural Change

Notes: ${ }^{*} a, b, c$, denotes significance levels at the $1 \%, 5 \%$ and $10 \%$, respectively. ${ }^{* *}$ Lag length selection criteria: MAIC. 
Table 3. Perron \& Rodriguez (2003) Unit Root Test with a Structural Change

\begin{tabular}{lcccccc}
\hline & \multicolumn{3}{c}{ Model with 1 break in Trend } & \multicolumn{3}{c}{ Model with 1 break in Constant \& Trend } \\
\hline & \multicolumn{3}{c}{ Statistics } & $k^{* *}$ & $T_{B}$ & \multicolumn{2}{c}{ Statistics } & $k^{*}$ & $T_{B}$ \\
\hline$M Z_{\alpha}$ & $-26.324^{b}$ & 5 & $1988 Q 1$ & $-69.721^{a}$ & 9 & $1985 Q 4$ \\
$M S B$ & $0.130^{b}$ & 5 & $1988 Q 1$ & $0.082^{a}$ & 9 & $1985 Q 4$ \\
$M Z_{t}$ & $-3.434^{b}$ & 5 & $1988 Q 1$ & $-5.762^{a}$ & 9 & $1985 Q 4$ \\
$A D F^{G L S}$ & -1.932 & 5 & $1982 Q 1$ & -2.208 & 8 & $2006 Q 3$ \\
$P_{T}$ & 14.153 & 5 & $1984 Q 1$ & 14.632 & 5 & $1983 Q 4$ \\
\hline
\end{tabular}

Notes: ${ }^{*} a, b, c$, denotes significance levels at the $1 \%, 5 \%$ and $10 \%$, respectively. ${ }^{* *}$ Lag length selection criteria: MAIC.

According to the tests of Elliott et al. (1996) and $\mathrm{Ng} \&$ Perron (2001) $\left(A D F_{M A I C}^{G L S}\right.$ and $\left.M_{M A I C}^{G L S}\right)$ - see Table 2-, it is not possible to reject the null hypothesis of unit root. Thus, according to theory, the unemployment rate in Spain behaves as if under a pattern of hysteresis. Nevertheless, as has been previously indicated, the presence of structural changes in the series could provoke a spurious non-rejection of the null hypothesis. In consequence, it is necessary to consider the inclusion of at least one break in the unit root tests. Taking into account the results of the unit root test with one structural change of Perron \& Rodríguez (2003) - see Table 3-, there is evidence to reject the null hypothesis $\mathrm{H}_{\mathrm{o}}$ : $\mathrm{I}(1)$, and the hysteresis hypothesis can be rejected. In consequence, we can conclude that the unemployment rate follows a structuralist model, which enables us to estimate an equilibrium rate for different regimes.

This result is especially relevant to understand the behavior of the unemployment rate in Spain. Thus, this means that the evolution in the unemployment rate in the middle- or long-run is independent of transitory shocks. The government's actions through economic policy measures can have an impact on the unemployment rate in the short-run, but will not have permanent effects unless reforms of structural reach are also applied.

Table 4. Bai-Perron Test Results

\begin{tabular}{cc}
\hline Statistics $^{*}$ & \\
\hline$U D_{\max }$ & $121.873^{\mathrm{a}}$ \\
$W D_{\max }(1 \%)$ & $136.622^{a}$ \\
$\sup F_{T}(1)$ & $48.872^{a}$ \\
$\sup F_{T}(2)$ & $121.873^{a}$ \\
$\sup F_{T}(3)$ & $52.566^{a}$ \\
$\sup F_{T}(4)$ & $29.517^{a}$ \\
$\sup F_{T}(5)$ & $21.314^{a}$ \\
$\sup F_{T}(2 \mid 1)$ & $85.949^{a}$ \\
$\sup F_{T}(3 \mid 2)$ & $77.438^{a}$ \\
$\sup F_{T}(4 \mid 3)$ & $28.407^{a}$ \\
$\sup F_{T}(5 \mid 4)$ & 4.459 \\
$B I C$ & 3 \\
LWZ & 3 \\
Sequencial & $4^{a}$ \\
\hline
\end{tabular}

Note: ${ }^{*} a, b, c, d$, denotes significance levels at the $1 \%, 2.5 \%, 5 \%$ and $10 \%$, respectively

After the times series analysis of the unemployment rate, the Ba-Perronis procedureis applied (Note 9). According to the LWZ criterion, we identified three structural changes for Spain, in 1981Q3, 1998Q4 and $2007 Q 1$ - see Tables 4 and 5-, so that the estimation of NAIRU for the whole of the Spanish economy allows us to identify four regimes or states. First and third regimes show similar moderate equilibrium rate of unemployment at close to $10 \%$; while second and fourth regimes register a higher rate, around $17 \%$. This result is especially worrying, since it implies that even under favorable economic circumstances, Spain has to endure a high level of structural unemployment. We consider these results, aside from differences in methodology and sample, as comparable to those of Papell et al. (2000) and Camarero et al. (2006b), which reinforce the validity of the present paper, especially when one takes into account that the first breakpoint estimated by us is very close to that estimated by those authors. (Note 10)

In order to establish the relation between changes in the equilibrium unemployment rate and the different labor reforms we will compare the dates in which the labor market reforms took place and the dates in which a change in NAIRU is registered. 
A priori, the estimated dates in which the changes in the unemployment rate take place $-1981 Q 3,1998 Q 4$ and $2007 Q 1-$ do not exactly match with the timing of any identified labor reform. However, in our opinion, two clarifications are necessary. The first is that, as is well known, the effects of a labor reform take hold on the job market with a certain lag, as a learning period is required from economic agents. Secondly, the passing of a labor reform tends to be followed by a series of Royal Decrees, supplementing laws, etc. that further develop the law and clarify the situations and assumptions modified by the reform. Because of this, many agents wait for a period of time before taking decisions related to hiring or laying off employees. In consequence, we consider that the estimated dates (through the Bai-Perron procedure) in which changes in the equilibrium rate took place are a reflection of the impact of the reforms of 1980, 1997 and 2006. (Note 11)

Table 5. Break dates and confidence intervals from Bai-Perron test (LWZ criteria)

\begin{tabular}{ccc}
\hline & Estimated break point & $\begin{array}{c}\text { 95\% Confidence } \\
\text { interval }\end{array}$ \\
\hline$\widehat{T}_{B 1}$ & $1981 Q 3$ & $(1981 Q 2: 1981 Q 4)$ \\
$\widehat{T}_{B 2}$ & $1998 Q 4$ & $(1997 Q 4: 1999 Q 1)$ \\
$\widehat{T}_{B 3}$ & $2007 Q 1$ & $(2003 Q 2: 2008 Q 1)$ \\
$\bar{R}^{2}$ & \multicolumn{2}{c}{0.635} \\
$F$ & 62.932 \\
\hline Regime & Estimated NAIRU & \\
\hline $1^{\text {st }}$ & $8.37^{a}$ & Corrected t-student \\
$2^{\text {nd }}$ & $17.92^{a}$ & coefficients \\
$3^{\text {rd }}$ & $10.81^{a}$ & 10.497 \\
$4^{\text {th }}$ & $17.03^{a}$ & 16.708 \\
& & 21.344 \\
\hline
\end{tabular}

Note: ${ }^{*} a, b, c$, denotes significance levels at the $1 \%, 5 \%$ and $10 \%$, respectively using freedom degree-adjusted critical values at two tails of the $t$-student

As can be seen in Figure 1, the effects on the equilibrium unemployment rate after those reforms took place are not homogeneous. Whereas after the reform of 1997 a reduction of $39.6 \%$ in that rate ensued, NAIRU increased $114 \%$ and $57.5 \%$ after the reforms of 1980 and 2006, respectively. In principle, these results can be confusing since, as has been pointed out, a reduction of the rigidities in the job market should not lead to an increase in NAIRU, but rather the opposite (IMF, 2003; OECD, 2003). However, we consider that these results are in line with the works of Ball (1997), Blanchard \& Wolfers (1999), and Storm \& Naastepad (2007). That is, changes in the equilibrium unemployment rate are not only the result of labor reforms, understood as structural changes in the labor market; NAIRU can also be affected by demand factors. The combination of those structural changes, together with the government's macroeconomic policy responses to changes in the business cycle, can cause both upward and downward shifts in NAIRU.

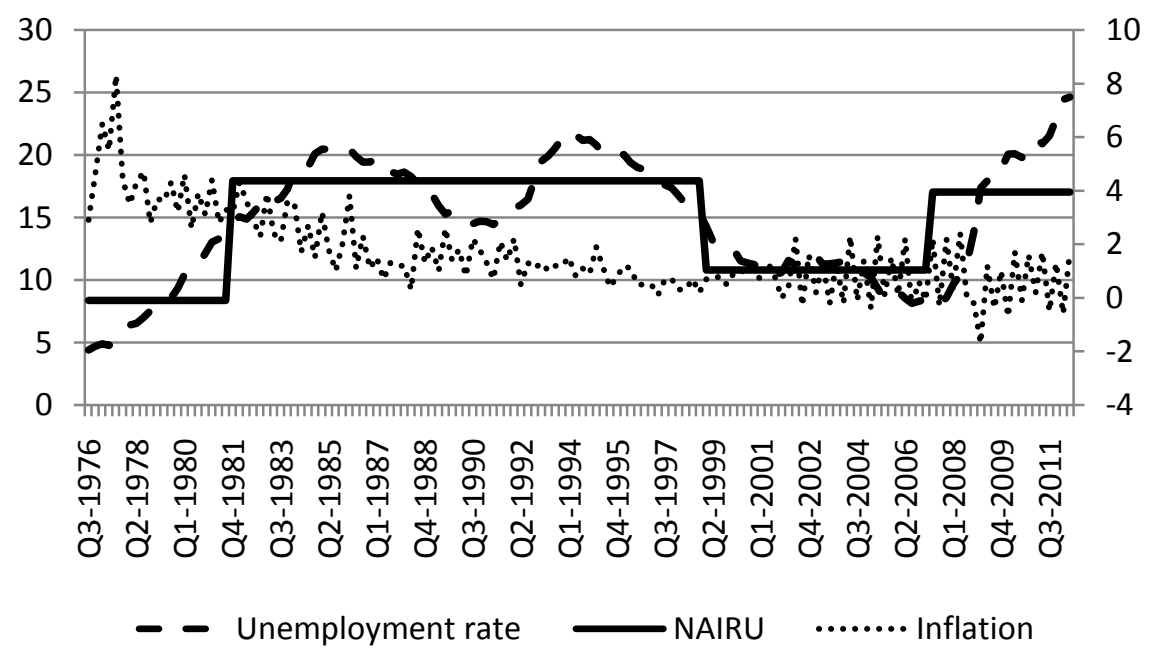

Figure 1. Unemployment Rate and NAIRU (\%) (Left axis) / Inflation Rate (\%) (Right axis)

Source: Compiled from LFS (INE) and OECD Stats 
Although it is beyond the scope of this analysis to dwell on such demand factors, it is easy to observe in Figure 1 how, in the case of Spain, the process of normalization in labor relations in the country - with the enactment of the Workers' Statute of 1980 - gives place to an increase in NAIRU. Thus, according to Palacio \& Álvarez (2004), that reform was the "kick start" for giving free rein to layoffs, an alternative that was not viable under the previous non-democratic political and institutional framework. At the same time, this increase in the observed unemployment rate translated into an increase in the equilibrium unemployment rate as a consequence of the political macroeconomic measures aimed at reducing the inflation rate. Once the inflation rate stabilized at low values, this might have allowed the equilibrium rate to decrease, which may have made the drop in inflation consistent with the reduction in the observed unemployment rate as encouraged by the reform of 1997.

One must nevertheless not forget that, as Toharia (2004) shows, the possible link between inflation and the unemployment rate must not be exaggerated, and that the unemployment rate and the variations in the equilibrium rate would not have taken place without the adjustment in the productive structure. That statement is, in our opinion, one of the possible factors explaining the increase in NAIRU after the Labor Reform of 2006, since the level of the inflation rate since 2007 has remained stable (see Figure 1). The bursting of the real estate bubble in that year had a devastating effect on the construction sector, and thus on NAIRU. Thus, Bentolila (2011) highlights that the end of this bubble led to a wide-scale destruction of non-qualified jobs that gave place to a "strong labor imbalance", as a result of the slow process of reallocation of that sector's workers into other activities. This fact, in our opinion, was likely the main factor behind the increase in the equilibrium rate. Basically, the same process as the one described above occurred in the eighties with the industrial sector (Bentolila \& Blanchard, 1990).

Table 6. Unemployment Rate, Unemployed and Employed people by activity sectors

\begin{tabular}{|c|c|c|c|c|c|c|c|c|}
\hline & \multicolumn{4}{|c|}{ Average Unemployment Rate $(\%)$} & \multicolumn{4}{|c|}{ Change of the Average Unemployment Rate (\%) } \\
\hline & Agriculture & Industry & Construction & Services & Agriculture & Industry & Construction & Services \\
\hline $\begin{array}{l}1976 Q 3 \\
1980 Q 1\end{array}$ & 3.13 & 4.17 & 14.10 & 2.96 & & & & \\
\hline $\begin{array}{l}1980 Q 2 \\
1997 Q 2\end{array}$ & 12.37 & 12.09 & 24.07 & 9.85 & 294.92 & 189.84 & 70.70 & 232.30 \\
\hline $\begin{array}{l}1997 Q 3 \\
2006 Q 2\end{array}$ & 15.54 & 6.89 & 10.12 & 8.04 & 25.62 & -43.02 & -57.96 & -18.37 \\
\hline $\begin{array}{l}2006 Q 3 \\
2012 Q 2\end{array}$ & 17.74 & 7.85 & 18.63 & 8.20 & 14.18 & 13.92 & 84.12 & 1.94 \\
\hline & Unemployed & y sector 0 & er Total Unem & loyed (\%) & Employed & y sector o & er Total Empl & yed (\%) \\
\hline & Agriculture & Industry & Construction & Services & Agriculture & Industry & Construction & Services \\
\hline $\begin{array}{l}1976 Q 3 \\
1980 Q 1\end{array}$ & 12.99 & 24.41 & 34.56 & 28.04 & 18.66 & 27.27 & 10.02 & 44.04 \\
\hline $\begin{array}{l}1980 Q 2 \\
1997 Q 2\end{array}$ & 11.81 & 23.36 & 21.35 & 43.48 & 12.51 & 23.40 & 9.18 & 54.91 \\
\hline $\begin{array}{l}1997 Q 3 \\
2006 Q 2\end{array}$ & 11.65 & 15.05 & 13.83 & 59.48 & 5.90 & 18.92 & 11.75 & 63.43 \\
\hline $\begin{array}{l}2006 Q 3 \\
2012 Q 2\end{array}$ & 8.48 & 11.76 & 20.14 & 59.62 & 4.21 & 14.98 & 10.39 & 70.42 \\
\hline
\end{tabular}

Source: Compiled from Data Base BDSICE of the Ministry of Economy and Competitiveness (MEC).

Those statements may find empirical support observing the behavior of some variables of the Spanish labor market when we disaggregate the unemployment rate by major economic sectors: Agriculture, Industry, Construction and Services. So, it can be seen in Table 6 how the average unemployment rate in the industrial sector it is multiplied by almost 3 after the labor reform of 1980. It is true that the increase in the average rates of unemployment in agriculture and services is higher but, however, it seems reasonable to consider that the increase in industry unemployment generated a structural problem in the Spanish labor market contributing to increase in the NAIRU. This assumption, in our opinion, can be observed according to the ratio between the number of unemployed in this sector and the total unemployed, which suffered no change from the previous period, despite the decreased in the importance of industrial sector in the aggregate employment. This fact, points to the difficulty for the Spanish economy to absorb unemployment from such sector.

The change in the NAIRU after the 1997 reform could be explained through the unemployment rate behavior of the construction and, again, industrial sector. This reform would have facilitated the absorption of structural 
unemployment in the construction and, especially, industrial sector, a fact which can be seen in the fall in the contribution of these sectors to the total number of unemployed in this period.

By contrast, the labor reform of 2006 would have been conditioned by the decline of the real-estate market. In this case, the increase in the NAIRU can only be influence by the unemployment rate behavior of the construction sector (see Figure 2), which was the variable that experienced the largest rise and, in addition to this, it has been the only sector that has seen growth its share in total unemployment.

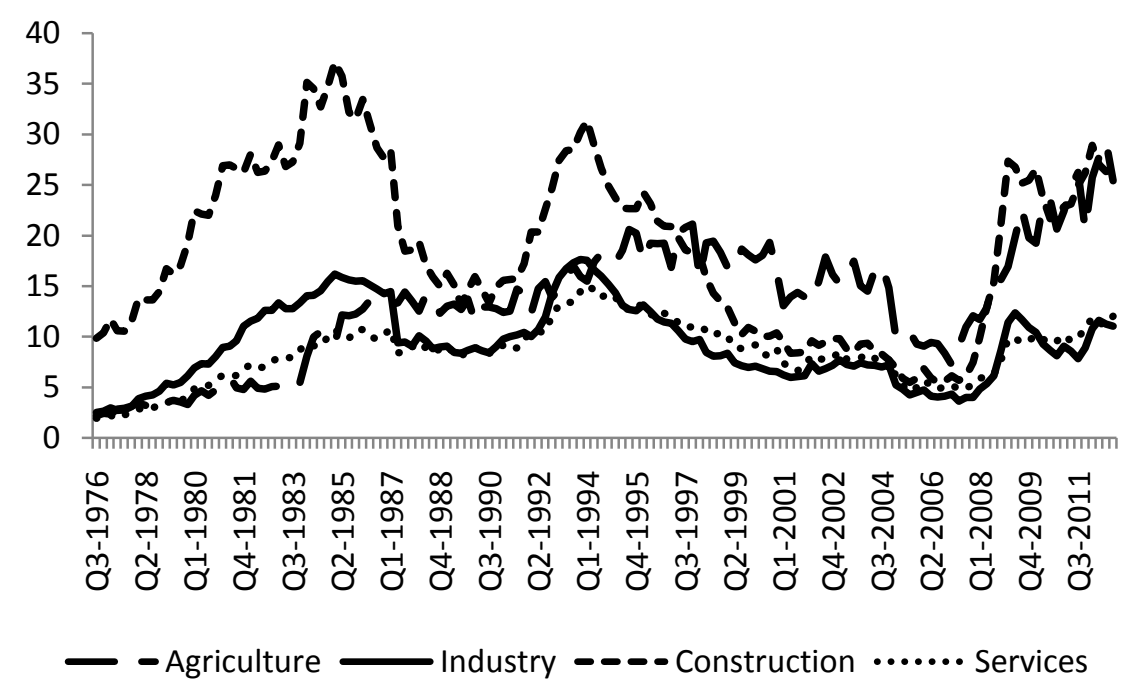

Figure 2. Unemployment Rate by activity sectors

Source: Compiled from Data Base BDSICE of the Ministry of Economy and Competitiveness (MEC).

\section{Discussion}

In this paper we analyzed the impact of the different labor reforms that have taken place in Spain on the Spanish labor market's equilibrium unemployment rate.

Given the behavior of the observed unemployment rate, we have demonstrated that the effects of these reforms depend in the short run on the business cycle, so that, as is mentioned on several occasions, a labor reform does not bring about job creation by itself, and thus, does not automatically lead to a reduction in the unemployment rate. In the case of the Spanish economy, this objective has been achieved in those periods in which its GDP has expanded at a rate close to, or higher than, $3 \%$.

Nevertheless, besides their short-term effects, labor reforms aim at bringing about structural changes that, in the long run, make possible the attainment of the lowest possible unemployment rate in the labor market. In order to assess whether those reforms had such an effect, we have first carried out a time series analysis of the unemployment rate in order to determine its characteristic structural pattern.

According to our results, the unit root hypothesis, and in consequence the hysteresis hypothesis, is rejected. This fact leads us to consider the structural hypothesis as the most adequate to characterize the national aggregate behavior, which is consistent with the use of a NAIRU as an adequate measure of the Spanish labor market. Thus, a simple but adequate estimation of NAIRU was provided for the Spanish economy during the sample period between 1976 and 2012. Furthermore, we have demonstrated the existence of multiple structural changes in the evolution of NAIRU that have caused shifts in this variable.

The obtained values show that the level of NAIRU swings between two states: high unemployment - with an equilibrium rate of approximately $17 \%$ - and low unemployment — with a rate of close to $10 \%$ - Such results are especially worrying for they place, in the best possible scenarios, the equilibrium unemployment rate in Spain at levels far higher than those considered of full employment.

The estimated break points for NAIRU are dated at 1981Q3, 1998Q4 and 2007Q1. These dates are compatible with three of the Labor Reforms enacted in 1980, 1997 and 2006, respectively. After the 1980 and 2006 reforms NAIRU increased, whereas after the 1997 reform NAIRU decreased. The observed change in the equilibrium rate after the reforms of 1980 and 2006 is not in line with what would be expected according to economic theory. However, when factors such as the stage of the business cycle, the evolution of the inflation rate and the change 
in the productive structure of the Spanish economy are taken into account, these results make sense and show that, as recent research suggests, labor reforms must be accompanied by other structural changes and/or macroeconomic policies in order to take full effect.

\section{Acknowledgements}

We are grateful to Managing Editor James Young, anonymous Referee, Professors Antonio Montañés and Enrique Viaña for their useful comments and suggestions. The authors also thank the comments received when a former version of this document was presented at the " $X$ Jornadas de Economía Laboral" in Madrid, Spain, 2013.

\section{References}

Andrés, J., Bentolila, S., Cabrales, A., Conde-Ruiz, J. I., de la Rica, S., Dolado, J. J., Messina, J. (2012). Un nuevo marco para las relaciones laborales en España, FEDEA. Retrieved from http://www.fedea.net/APIE/nuevo-marco-reforma-laboral/nuevo_marco_laboral_v2.pdf

Andrés, J., Dolado, J. J., Molinas, C., Sebastian, M., \& Zabalza, A. (1988). La influencia de las restricciones de demanda y de capital en el desempleo en España. In S. Bentolila, \& L.Toharia (Eds.) (1991), Estudios de Economía del Trabajo en España (III). El problema del Paro (pp. 777-866). Madrid, Spain: Ministerio de Trabajo y Seguridad Social (MTSS).

Andrés, J., Domenech, R., \& Taguas, D. (1996). Desempleo y ciclo económico. Moneda y Crédito, 201, $157-188$

Arestis, P., \& Mariscal, I. B. F. (1999). Units roots and structural breaks in OECD unemployment. Economics Letters, 65(2), 149-156. http://dx.doi.org/10.1016/S0165-1765(99)00131-7

Arestis, P., \& Mariscal, I. B. F. (2000). OECD unemployment: structural breaks and stationarity. Applied Economics, 32(4), 399-403. http://dx.doi.org/10.1080/000368400322570

Bai, J., \& Perron, P. (1998). Estimating and testing linear models with multiple structural changes. Econometricam, 66(1), 47-78. http://www.jstor.org/stable/2998540

Bai, J., \& Perron, P. (2003a). Computation and analysis of multiple structural change models. Journal of Applied Econometrics, 18, 1-22. http://dx.doi.org/10.1002/jae.659

Bai, J., \& Perron, P. (2003b). Critical values for multiple structural change tests. Econometrics Journal, 6, 72-78. http://dx.doi.org/10.1111/1368-423X.00102

Bai, J., \& Perron, P. (2006). Multiple structural change models: A simulation analysis. In D. Corbea, S. Durlauf, $\&$ B. E. Hansen (Eds.), Econometric Theory and Practice: Frontiers of Analysis and Applied Research (pp. 212-237). Cambridge, MA: Cambridge University Press.

Ball, L. (1997). Disinflation and the NAIRU. In C. D. Romer, \& D. H. Romer (Eds.), Reducing Inflation: Motivation and Strategy (pp. 167-194). Chicago: University of Chicago Press.

Ball, L., \& Mankiw, N. G. (2002). The NAIRU in theory and practice. Journal of Economic Perspectives 16(4), 115-136. http://dx.doi.org/10.1257/089533002320951000

Bhargava, A. (1986). On the theory of testing for unit root in observed time series. Review of Economic Studies, 53(3), 369-384. http://dx.doi.org/10.2307/2297634

Bellod, J. F. (1999). Prueba de causalidad y determinación de la NAIRU. El Trimestre Económico, 66(264), $663-692$.

Bentolila, S. (2011). ¿Por qué han divergido tanto las tasas de paro de España y Francia durante la Gran Recesión? FEDEA. Retrieved from http://www.fedeablogs.net/economia/?p=9207

Bentolila, S. (2013). La reforma laboral y la destrucción de empleo. FEDEA. Retrieved from http://www.fedeablogs.net/economia/?p=28700

Bentolila, S., \& Bertola, G. (1990). Firing costs and labor demand: How bad is eurosclerosis? Review of Economic Studies, 57(3), 381-402. http://dx.doi.org/10.2307/2298020

Bentolila, S., \& Blanchard, O. J. (1990). Spanish Unemployment. Economic Policy, 10(5), 233-281.

Bentolila, S., \& Jimeno, J. F. (2006). Spanish Unemployment: The End of the Wild Ride? In M. Werding (Ed.), Structural Unemployment in Western Europe: Reasons and Remedies, MIT Press.

Blanchard, O. J. (2006). European unemployment: the evolution of facts and ideas. Economic Policy, 21(45), 
5-59. http://dx.doi.org/10.1111/j.1468-0327.2006.00153.x

Blanchard, O. J., \& Jimeno, J. F. (1999). Reducing Spanish unemployment under the EMU. FEDEA, Working Paper 99-02.

Blanchard, O. J., \& Summers, L. H. (1986). Hysteresis and the European unemployment problem. Macroeconomics Annual 1986, pp. 17-78. National Bureau of Economic Research (NBER)

Blanchard, O. J., \& Wolfers, J. (1999). The Role of Shocks and Institutions in the Rise of European Unemployment: The Aggregate Evidence. Working Paper no. 7282. National Bureau of Economic Research (NBER), Cambridge, Mass.

Camarero, M., Carrion-i-Silvestre, J. L., \& Tamarit, C. (2005). Unemployment dynamics and NAIRU estimates for accession countries. A univariate approach. Journal of Comparative Economics, 33(3), 584-603. http://dx.doi.org/10.1016/j.jce.2005.04.001

Camarero, M., Carrion-i-Silvestre, J. L., \& Tamarit, C. (2006a). Short-term modified Phillips curves for the accession countries. Applied Economics Letters, 13, 159-162. http://dx.doi.org/10.1080/13504850500394277

Camarero, M., Carrion-i-Silvestre, J. L., \& Tamarit, C. (2006b). Testing for hysteresis in unemployment in OECD countries: New Evidence using stationarity panel tests with breaks. Oxford Bulletin of Economics and Statistics, 68(2), 167-182. http://dx.doi.org/10.1111/j.1468-0084.2006.00157.x

CEPR. (1994). El paro en España: ¿Tiene solución? Informe conjunto. In O. J. Blanchard \& J. F. Jimeno (Eds.), El paro en España: ¿Tiene solución? (pp. 5-19). Madrid, Spain: Centre for Economic Policy Research (CEPR).

CES. (2000). Memoria sobre la situación socioeconómica y laboral de España 1999. Madrid, Spain: Consejo Económico y Social (CES).

Clemente, J., Lanaspa, L., \& Montañés, A. (2005). The unemployment structure of the US states. The Quarterly Review of Economics and Finance, 45(4-5), 848-868. http://dx.doi.org/10.1016/j.qref.2004.12.021

Conde-Ruiz, J. I., Felgueroso, F., \& García, J. I. (2010). Las reformas laborales en España: un modelo agotado. Colección de Estudios Económicos 11-2010, FEDEA.

De Lamo, A. R., \& Dolado, J. J. (1993). Un modelo del mercado de trabajo y la restricción de oferta en la economía española. Investigaciones Económicas, 17(1), 87-118.

DeJong, D. N., Nankervis, J. C., Savin, N. E., \& Whiteman, C. H. (1992). Integration Versus Trend Stationary in Time Series. Econometrica, 60(2), 423-433.

Dirección General de Previsión y Coyuntura (DGPC). (1991). El sistema de ecuaciones precios-salarios y la tasa natural de paro. Síntesis Mensual de Indicadores Económicos, diciembre, pp. XVII-XXV.

Dolado, J. J., Malo de Molina, J. L., \& Zabalza, A. (1986). El Desempleo en el Sector Industrial. In S. Bentolila, \& L. Toharia (Eds.) (1991), Estudios de Economía del Trabajo en España (III). El Problema del Paro(pp. 737-776). Madrid, Spain: Ministerio de Trabajo y Seguridad Social (MTSS).

Durán, C., \& Ramos, R. (2006). Evolución de la NAIRU en la economía española: una estimación mediante el filtro de Kalman. Estudios de Economía Aplicada, 24(2), 845-867.

Elliot, G., Rothenberg, T. J., \& Stock, J. H. (1996). Efficient tests for an autoregressive unit root. Econometrica 64(4), 813-836. http://www.jstor.org/stable/2171846

Escudero, M., Jimeno, J. F., Allard, G., \& López-García, P. (2004). El mercado laboral en España: Análisis y reformas. Retrieved from www.ie.edu/iefund/docs/Tinker.doc.

Espinosa-Vega, M. A., \& Russell, S. (1997). History and theory of the NAIRU: A critical review. Federal Reserve Bank of Atlanta Economic Review, 82(2), 4-25.

Estrada, A., González-Calbet, L., \& Kessler, A. (2011). Evaluando los efectos a largo plazo de la reforma laboral en España. In Ministry of Economy and Finance, Documentos de Trabajo 2011/2

Estrada, A., Hernando, I., \& López-Salido, D. (2002). La medición de la NAIRU en la economía española. Moneda y Crédito, 215, 69-107.

Ewing, B. T., \& Wunnava, P. V. (2001). Unit roots and structural breaks in North American unemployment rates. The North American Journal of Economics and Finance, 12, 273-282. http://dx.doi.org/10.1016/S1062-9408(01)00055-9 
García, P. (1999). Las modalidades de contratación en España: algunas consideraciones sobre el impacto de la última reforma. In Bank of Spain, Boletín Económico Julio-Agosto, 1999.

Gómez García, F., Rebollo Sanz, Y., \& Usabiaga Ibáñez, C. (2002). Nuevas estimaciones de la NAIRU de la economía española: métodos directos. Estudios de Economía Aplicada, 20(3), 509-530.

Gómez García, F., \& Usabiaga Ibáñez, C. (2001a). Las estimaciones del desempleo de equilibrio. Una panorámica. Revista de Economía Aplicada, 27, 103-129.

Gómez García, F., \& Usabiaga Ibáñez, C. (2001b). ¿Dónde está situada la NAIRU de la economía española? Boletín Económico de ICE 2690, 9-17.

Gómez, S., Contreras, I., \& Gracia, M. D. (2008). Las reformas laborales en España y su impacto real en el mercado de trabajo en el período 1985-2008. Cátedra SEAT, IESE Business School. Retrieved from www.iese.edu/es/files/ReformasLaborales.pdf

Hopenhayn, H., \& Rogerson, R. (1993). Job turnover and policy evaluation: A general equilibrium analysis. Journal of Political Economy, 101(5), 915-938. http://www.jstor.org/stable/2138602

IMF. (2003). Unemployment and Labor Market Institutions: Why Reforms Pay Off. In World Economic Outlook 2003. Washington, DC: International Monetary Fund (IMF), April 2003, 129-150.

Jaeger, A., \& Parkinson, M. (1994). Some evidence on hysteresis in unemployment rates. European Economic Review, 38(2), 329-342. http://dx.doi.org/10.1016/0014-2921(94)90061-2

Jimeno, J. F., \& Toharia, L. (1992). El mercado de trabajo español en el proceso de convergencia hacia la Unión Económica y Monetaria Europea. Papeles de Economía Española, 52/53, 78-107.

Layard, R., Nickell, S., \& Jackman, R. (Eds.). (1991). Unemployment. Macroeconomic performance and the labour market. Oxford: Oxford University Press.

Liu, J., Wu, S., \& Zidek, J. V. (1997). On Segmented Multivariate Regressions. Statistica Sinica, 7, 497-525.

Malo, M. A., \& Toharia, L. (1997). Economía y derecho del trabajo: las reformas laborales de 1994 y 1997. Cuadernos Económicos de I.C.E., 63, 155-174.

McMorrow, K., \& Roeger, W. (2000). Time-varying NAIRU/NAWRU estimates for her EU's member states. European Commission. Directorate-General for Economic and Financial Affairs, Economic Papers 145.

Mitchell, W. F. (1993). Testing for unit roots and persistence in OECD unemployment rates. Applied Economics, 25(12), 1489-1501. http://dx.doi.org/10.1080/00036849300000153

Modigliani, F., \& Papademos, L. (1975). Targets for monetary policy in the coming year. Brookings Papers on Economic Activity, 1, 141-163.

Montañés, A., \& Reyes, M. (1998). The asymptotic behaviour of the Dickey-Fuller unit root tests under a shift in the trend function. Econometric Theory, 14(3), 355-363. http://www.jstor.org/stable/3532773

Montero, J. M. (2000). Dinámica conjunta de la inflación y el paro en España: Un enfoque de incoherencia temporal de la política monetaria. CEMFI t0006.

Ng, S., \& Perron, P. (2001). Lag length selection and the construction of unit root tests with good size and power. Econometrica, 69(6), 1519-1554. http://www.jstor.org/stable/2692266

OECD. (1999). Employment protection and labour market performance. In Employment Outlook 1999, OECD, Paris, pp. 48-132.

OECD. (2003): The Sources of Economic Growth. Paris: OECD.

Palacio, J. I., \& Álvarez, C. (Eds.). (2004). El mercado de trabajo: Análisis y políticas. Madrid, Spain: Akal.

Papell, D. H., Murray, C. J., \& Ghiblawi, H. (2000). The structure of unemployment. The Review of Economics and Statistics, 82(2), 309-315. http://dx.doi.org/10.1162/003465300558696

Payne, J. E., Ewing, B. T., \& George, E. P. (1999). Time series dynamics of US state unemployment rates. Applied Economics, 31(11), 1503-1510. http://dx.doi.org/10.1080/000368499323364

Perron, P. (1989). The great crash, the oil price shock and the unit root hypothesis. Econometrica, 57(6), 1361-1401. www.jstor.org/stable/1913712

Perron, P. (1994). Trend, Unit Root and Structural Change in Macroeconomic Time Series. In B. B. Rao (Ed.), Cointegration for the Applied Economist (pp. 113-146). Basingstoke: Macmillan Press. 
Perron, P., \& Ng, S. (1996). Useful modifications to some unit root tests with dependent errors and their local asymptotic properties. Review of Economic Studies, 63(3), 435-463. http://dx.doi.org/10.2307/2297890

Perron, P., \& Ng, S. (1998). An autoregressive spectral density estimator at frequency zero for nonstationarity tests. Econometric Theory, 14(5), 560-603.

Perron, P., \& Rodríguez, G. (2003). GLS detrending, efficient unit root tests and structural change. Journal of Econometrics, 115(1), 1-27. http://dx.doi.org/10.1016/S0304-4076(03)00090-3

Phelps, E. S. (Ed.). (1994). Structural Slumps: The Modern Equilibrium Theory of Unemployment, Interest, and Assets. Cambridge, MA: Harvard University Press.

Phillips, P.C.B. (1987). Time series regression with unit roots. Econometrica, 55(2), 277-302. http://www.jstor.org/stable/1913237

Phillips, P .C. B., \& Perron, P. (1988). Testing for a unit root in time series regression. Biometrika, 75, 335-346. http://www.jstor.org/stable/2336182

Rodríguez-Prado, B. (1995a). La tasa natural de desempleo en la economía española: Un intento de cuantificación. Estudios de Economía Aplicada, 3, 133-152.

Rodríguez-Prado, B. (1995b). The persistence of unemployment and the natural rate in Spain. International Advances in Economic Research, 1(4), 417-425. http://dx.doi.org/10.1007/BF02295794

Roed, K. (1996). Unemployment hysteresis - Macro evidence from 16 OECD countries. Empirical Economics, 21(4), 589-600. http://dx.doi.org/10.1007/BF02295794

Roed, K. (1997). Hysteresis in unemployment. Journal of Economic Surveys, 11(4), 389-418. http://dx.doi.org/10.1111/1467-6419.00040

Ruiz, E. (2006). Las reformas laborales en España (1977-2002). Laberinto, 20, 7-22.

Saint-Paul, G. (1995). The high unemployment trap. Quarterly Journal of Economics 110(2), 527-550. http://dx.doi.org/10.2307/2118449

Saint-Paul, G. (1997). The rise and persistence of rigidities. American Economic Review, 87(2), 290-294. http://www.jstor.org/stable/2950933

Saint-Paul, G. (2002a). The political economy of employment protection. Journal of Political Economy, 110(3), 673-704. http://www.jstor.org/stable/10.1086/339744

Saint-Paul, G. (2002b). Macroeconomic fluctuations and the timing of labour market reforms. CEPR Discussion Paper 3646.

Segura, J. (2001). La reforma del mercado de trabajo español. Un panorama. Revista de Economía Aplicada 25, $157-190$.

Siebert, H. (1997). Labor market rigidities: At the root of unemployment in Europe. Journal of Economic Perspectives, 11(3), 37-54. http://dx.doi.org/10.1257/jep.11.3.37

Stock, J. H. (1999). A class of tests for integration and cointegration. In R. F. Engle, \& H. White (Eds.), Cointegration, Causality and Forecasting. A Festschrift in Honour of Clive W.J. Granger (pp. 137-167). Oxford: Oxford University Press.

Storm, S., \& Naastepad, C. W. M. (2007). It is High Time to Ditch the NAIRU. Journal of Post Keynesian Economics, 29(4), 531-554. http://dx.doi.org/10.2753/PKE0160-3477290401

Tobin, J. (1980). Stabilization policy ten years after. Brookings Papers on Economic Activity, 1, 19-71.

Toharia, L. (2004). El mercado de trabajo en España: Situación y perspectivas. clm.economía, 4(1), 77-106.

Zivot, E., \& Andrews, D. W. K. (1992). Further evidence on the great crash, the oil-price shock and the unit root hypothesis. Journal of Business and Economics Statistics, 10(3), 251-270. http://www.jstor.org/stable/1391541

\section{Notes}

Note 1: The original term established by the authors was NIRU (Non Inflationary Rate of Unemployment), although Tobin (1980) later introduced the term NAIRU. For a more detailed history of the term, see Espinosa-vega and Russell (1997).

Note 2: Thus, for example, for the year 2000 the estimation of that rate was within a large interval between $13 \%$ and $18 \%$, whereas until the mid-1990s, those estimations followed an upward trend, reaching levels between $17 \%$ and $21 \%$, depending 
on the methodology employed.

Note 3: One might argue that, in addition to the reforms hereby referenced, one could include two more reforms of 1992 and 2011. However, given that these reforms are not taken into account by all authors, we have opted to leave them out of the analysis.

Note 4: Under the general criterion, we will take as reference the enactment of the Workers' Statute of 1980. However, to be more precise, the reforms associated with this period had already started in 1979 with the signing of the "Acuerdo Marco Interconfederal (AMI)".

Note 5: Although this is the most widespread interpretation, Saint-Paul (2002b) considers that argument is not necessarily true.

Note 6: The Zivot \& Andrews (1992) method is known as the infimum method. See Perron \& Rodríguez (2003) for further details regarding the choice of the break point and other aspects.

Note 7: It is assumed that inflation follows a random walk and that, in consequence, variations in inflation are stationary. That is, the $\varepsilon$ disturbance is stationary. In our case, the ADF test applied to the monthly inflation rate in Spain for the period 1978M2 and 2012M6 rejects the hypothesis of unit root (results available upon request to the authors).

Note 8: The unemployment rate in Spain is calculated on the basis of the Labor Force Survey (LFS), compiled by the National Institute of Statistics (INE) on a quarterly basis.

Note 9: Following the practical recommendations of Bai \& Perron (2003a, 2006), we utilize a trimming $\varepsilon=0.15$, which allows a maximum of 5 breaks. Furthermore, we allow the existence of correlation in errors and different variances in residuals and data between segments and subsamples. According to the same authors, these specifications improve the power of the tests and the precision in selecting the number of breaks.

Note 10: According to Papell et al. (2000), the value of NAIRU for the Spanish economy prior to 1980 was $6.11 \%$, whereas after that structural change it located at $19.28 \%$ until the end of the sample. In Camarero et al. (2006b), the break point is also located in 1980. In that paper, the NAIRU estimated prior to the break point of 1980 was almost $7 \%$, whereas after the break it rises to $18.1 \%$. It is worth highlighting that in these papers, standardized unemployment rates with a yearly frequency are employed, in comparison to the present study which utilizes quarterly rates without correcting for seasonal effects (not mentioning possible methodological differences arising from the utilized definitions). Thus, we consider that the difference between the break point as estimated by us and those authors is not significant.

Note 11: Thus, for example, the labor reform enacted in the Interconfederal Agreement on Labor Stability (AIEE), although signed in April 1997, caused an acceleration in job creation starting in 1999, which coincided with the Royal Decree of Urgent Measures for the Improvement of the Labor Market of November $27^{\text {th }}$, 1998, as pointed out in the Economic Bulletin of the Bank of Spain (1999) — see García (1999) — and in the CES (2000) Yearbook.

\section{(cc) EY}

This work is licensed under a Creative Commons Attribution 3.0 License. 